\title{
Duch Święty jako żywioły natury w symbolicznych interpretacjach Starego Testamentu w tradycji łacińskiej
}

\author{
The Holy Spirit as Elements of Nature in Symbolic Interpretations \\ of the Old Testament in the Latin Tradition
}

\author{
KRZYSZTOF BARDSKI \\ Uniwersytet Kardynała Stefana Wyszyńskiego, Warszawa \\ kbardski@yahoo.com, ORCID: 0000-0002-8340-3993
}

Streszczenie: Artykuł stanowi owoc badań nad patrystyczną i średniowieczną symboliką Ducha Świętego, na podstawie tekstów Starego Testamentu, wyrażoną przy pomocy obrazów sił natury, takich jak wiatr, woda i ogień. Zostały przedstawione i omówione najważniejsze interpretacje należące do tradycji Kościoła łacińskiego.

Słowa kluczowe: Pismo Święte; Duch Święty; symbol; alegoria; wiatr; woda; ogień

Abstract: The article is the fruit of research on the patristic and medieval symbolism of the Holy Spirit, based on the texts of the Old Testament, as expressed through the help of images of elements of nature, such as wind, water and fire. The most important of such interpretations belonging to the traditions of the Latin Church are presented and discussed.

Keywords: Holy Bible; Holy Spirit; symbol; allegory; wind; water; fire

Objawienie Boże w tekście Pisma Świętego ma charakter stopniowy. Na przestrzeni historii, pośród zmieniających się kontekstów kulturowych, kolejne księgi wnosiły nowe treści doktrynalne, nieobecne często we wcześniejszych pismach. Zjawisko to jest możliwe do zaobserwowania już na kartach Starego Testamentu, jednak zasadniczy przełom dokonał się wraz z Wcieleniem Jezusa Chrystusa i powstaniem Nowego Testamentu. Księgi Nowego Przymierza są oczywiście głęboko zakorzenione w Starym Testamencie, tym niemniej istotne treści doktrynalne odróżniają je od przesłania ksiąg Pierwszego Przymierza. Jedną z tych treści jest tajemnica Trójcy Świętej. W tekście Starego Testamentu jawi się ona jako zapowiedź prorocka, zwłaszcza w odniesieniu do Mesjasza, nie należy jednak do przekazu na poziomie historycznym i literalnym tekstu. Stąd też - z perspektywy redukcyjnie rozumianego monoteizmu - zarówno zapowiedzi mesjańskie, jak i teksty dotyczące daru Ducha (np. „Ducha nowego tchnę do waszego wnętrza” - Ez 36,26; lub „Twój dobry Duch 
niech mnie prowadzi” - Ps 143,10) niekoniecznie muszą odnosić się do Osób Trójcy Świętej.

Czytając jednak Stary Testament z perspektywy chrześcijańskiej, zwłaszcza biorąc pod uwagę klucz hermeneutyczny św. Augustyna, w myśl którego „Nowy Testament jest ukryty w Starym, natomiast Stary znajduje wyjaśnienie w Nowym"1, uwzględniając „analogię wiary”, jako spójność prawd wiary między sobą i w całości planu Objawienia ${ }^{2}$, oraz traktując Biblię z tzw. perspektywy kanonicznej jako jedną księgę ${ }^{3}$, na przestrzeni wieków chrześcijanie odczytywali niektóre motywy literackie Starego Testamentu w kluczu pneumatologicznym, czyli odnosząc je w sposób symboliczny do Ducha Świętego. Ze względu na obszerny zakres tematyczny, skupimy się na trzech żywiołach natury, które szczególnie inspirowały wyobraźnię chrześcijan starożytności i średniowiecza, by doszukiwać się w nich obrazu lub manifestacji Ducha Świętego: wiatr, woda i ogień.

\section{Duch Święty jako wiatr}

Motyw wiatru we wszystkich kulturach cechował się olbrzymią nośnością symboliczną. Rozróżnia się zasadniczo pozytywną wymowę symboliki lekkiego powiewu, kojarzonego z oddechem, a więc objawem życia, oraz ambiwalentną wymowę potężnego wichru, który z jednej strony może obrazować kosmiczną potęgę bóstwa, z drugiej zaś - jego niszczycielską moc lub potęgę demonów. W swoim dziele poświęconym symbolice biblijnej, Marc Girard ${ }^{4}$ klasyfikuje symbol wiatru w kategorii symboli zarówno teofanicznych, czyli wyrażających obecność bóstwa, jak i ponerologicznych, czyli odwołujących się do kategorii zła, zniszczenia i śmierci. Na ten aspekt symboliki wiatru w Psalmach zwrócił uwagę w swoim artykule Steve A. Wiggins.

Z perspektywy archetypicznej wiatr przywołuje na myśl tajemnicze działanie niewidzialnej siły: ruch niewidocznego powietrza umyka ludzkiej kontroli. Starożytni nie znali atmosferycznych uwarunkowań powodujących przesuwanie się mas powietrza, stąd przypisywali im moc kosmiczną, łącząc wichry z czterema punktami kardynalnymi ziemi lub z mocami niebios ${ }^{6}$. Od strony percepcji ludzkiej, wiatr przywoływał na myśl nieprzewidywalność i zmienność. Jedynie ogólnie łączono poszcze-

\footnotetext{
1 Augustyn, Quaestiones in Heptateuchum, 2,73 (CCL 33,106; PSP 46,121); Sobór Watykański II, Dei verbum, 16; Katechizm Kościoła Katolickiego, 129.

2 Por. Katechizm Kościoła Katolickiego, 114.

3 Por. Benedykt XVI, Verbum Domini, 34.

4 Por. Girard, Les symboles dans la Bible; na temat symboliki wiatru zob. rozdział 4 (313-447).

5 Por. Wiggins, „Tempestuous Wind”, 3-23.

6 Por. Cirlot, Słownik symboli, 446-447.
} 
gólne wiatry z porami roku, nie mogąc jednak przewidzieć ani ich intensywności, ani szkód, jakie mogą wyrządzić.

Skojarzenie Ducha Świętego z wiatrem ma genezę etymologiczną. Zarówno w języku hebrajskim $\left(r \hat{u}^{a} h\right)$, jak i greckim (pneuma) to samo określenie w kontekście zjawisk atmosferycznych oznacza „wiatr”, zaś w kontekście osobowym odnosi się do "ducha”. Ta swoista dwuznaczność czasami stawia tłumacza Biblii przed trudnym wyzwaniem, jak choćby w przypadku słynnego tekstu z J 3,8: „Pneuma wieje tam, gdzie chce i szum jego słyszysz, lecz nie wiesz, skąd pochodzi i dokąd podąża. Tak jest z każdym, kto narodził się z Pneuma”. Poza kwestią etymologiczną samo zjawisko potężnego wichru kojarzy się z mocą Ducha Bożego. Wicher jest niewidzialną potęgą (starożytni nie łączyli go z przemieszczaniem się mas powietrza), która jednak jest odczuwalna i można doświadczyć jej skutków.

W szczególności symbolikę wiatru południowego odnoszono do Ducha Świętego. Grzegorz Wielki (+604) widzi w wietrze z południa Ducha Świętego, który wyzwala od wszelkiej oziębłości i nieprawości ${ }^{7}$, zaś anonimowy autor ${ }^{8}$, któremu przypisywany jest komentarz Bedy Czcigodnego (+735) do Pięcioksięgu, powie, że wiatr południowy, który rozdzielił wody Morza Czerwonego, symbolizuje Ducha posłanego przez Chrystusa, który przegania od świętych pokusy światowe9. Podobnie Alkuin (+804) w kompilacyjnym dziele De divinis officiis dostrzeże w łagodnym powiewie wiatru z południa Ducha Świętego, który głaszcząc czule ludzkie serce, rozpala $\mathrm{w}$ nim płomień miłości ${ }^{10}$. Ponadto ciepło wiatru z południa pochodzi od samego Słońca, którym w chrześcijańskiej symbolice jest Jezus Chrystus, oświetlającego ziemię od wschodu aż po zachód ${ }^{11}$.

Motyw wiatru z południa pojawia się w Pnp 4,14: „Powstań, wietrze północny, nadleć, wietrze z południa, wiej poprzez ogród mój, niech popłyną jego wonnościl”. Zasadniczo Ojcowie Kościoła widzieli w tym wersecie przeciwstawienie zła i Szatana (chłodny wiatr z północy), który ma „powstać”, aby zostać przegnany, Duchowi Świętemu (gorący wiatr z południa ${ }^{12}$ ), który ma "nadlecieć" przyobiecany przez Chrystusa $^{13}$. Grzegorz Wielki wyjaśnia w Moraliach do Księgi Hioba: „Wiatr południowy przychodzi i przewiewa ogród, aby popłynęły jego wonności, bowiem gdy umysł człowieka napełnia się w czasie przyjścia Ducha Świętego, natychmiast wydobywa się z niego sława jego cnót, tak że język świętych, jak ogród przewiany wiatrem

\footnotetext{
Por. Grzegorz Wielki, Moralia in Job, 27, 38, 63 (CCL 143B,1381; ŹM 75,353).

Na temat atrybucji dzieła zob. K. Bardski, Słowo oczyma Gołębicy, 266.

Por. Pseudo-Beda, Commentarii in Pentateuchum. In Exodum, 14 (PL 91,310D).

Por. Alkuin (Pseudo-Beda), De divinis officiis (PL 101,1250D).

Por. Jan z Rouen, De officiis ecclesiasticis. Ad Maurilium, 50 (PL 147,33D).

Por. Aelred z Rievaulx, In adventu Domini, 15 (PL 184,824C).

3 Por. Rupert z Deutz, Commentariorum in duodecim prophetas minores, 3 (PL 168,629C). Podobnie wodniesieniu do Hab 3,3; por. Gerhohus z Reichesberg, Expositio in canticum Habacuc, ad 3,3 (PL 194,1030C).
} 
południowym, słusznie może już mówić: Jesteśmy dla Boga miłą wonią Chrystusa (2Kor 2,15). Odzienie świętego Kościoła staje się zatem ciepłe, gdy ziemię owiewa wiatr południowy. Ci bowiem, którzy jednoczą się z nim przez wiarę, jaśnieją wielką gorliwością w miłości w chwili, gdy ich umysł jest wypełniony powiewem Ducha Świętego"14. Mnich Angelomus z Luxeuil (+895) doda, iż Duch Święty, jak powiew wiatru z południa, usuwa wszelki chłód duchowy ${ }^{15}$.

Drugi werset przywoływany w tym kontekście pochodzi z Ps 126,4 („Odmień nasz los, o Panie, jak strumienie w Negebie”), który w tłumaczeniu Wulgaty brzmiał: „Odmień, Panie naszą niewolę, jak strumień wiatrem południowym” (Converte, Domine, captivitatem nostram sicut torrens in austro $)^{16}$. Alan z Lille (+1203) wyjaśnia, że Duch Święty swoim ciepłym powiewem topi zmarzlinę niewiary ludzkiego serca, aby - jak strumień - mógł popłynąć ku Bogu ${ }^{17}$. Brunon z Würzburga $(+1045)$ dopowie, że dokonuje się to wówczas, gdy człowiek żałuje za swoje grzechy i dostępuje przebaczenia $^{18}$. Zaś Piotr Lombard (+1164) w komentarzu do Psalmów również przy okazji tego wersetu rozwija przeciwstawienie ciepłego powiewu Ducha Świętego chłodnemu powiewowi ducha szatańskiego ${ }^{19}$.

Pseudo-Garnier z Langres (+po 1225), przypuszczalnie opierając sie na De universo Rabana Maura $(+856)^{20}$, łączy z symboliką Ducha Świętego motyw wiatru z Ps 135,7 („który dobywa wiatry ze swych skarbców”), przy czym w jego interpretacji wiatrami są dary Ducha Świętego, które Pan wydobywa z serc wierzących, by służyły wspólnocie ${ }^{21}$.

14 Auster enim venit et hortum perflat, ut eius aromata diffluant, quia per adventum sancti Spiritus, dum mens hominum repletur, ex ea mox opinio virtutum aspergitur, ut iure iam sanctorum lingua quasi hortus Austro perflatus dicat: Christi bonus odor sumus Deo (I Cor. II, 15). Vestimenta ergo sanctae Ecclesiae calida sunt, dum terra Austro perflatur, quia hi qui ei per fidem inhaerent, ferventibus charitatis studiis inardescunt, dum eorum mens sancti Spiritus afflatu perfunditur (Grzegorz Wielki, Moralia in Job, 27, 38, 63 (CCL 143B,1381; ŹM 75,353).

15 Por. Angelomus z Luxeuil, Enarrationes in Cantica canticorum, ad 4,14 (PL 115,611D).

16 Różnica pomiędzy Wulgatą a współczesnymi tłumaczeniami wynika z dwuznaczności hebrajskiego terminu negeb. Oznacza on, jako nazwa własna, obszar pustynny na południe od Judei, zaś przez metonimię odnosi się również do południowej strony świata.

17 Por. Alan z Lille, Distinctiones dictionum theologicalium. Torrens (PL 210,976D).

18 Por. Brunon z Würzburga, Expositio Psalmorum, ad 125,4 (PL 142,471C).

19 Por. Piotr Lombard, Commentaria in Psalmos, ad. loc. (PL 191,1155B).

20 Por. Raban Maur, De universo, 25. De ventis (PL 111,281C).

21 Por. Pseudo-Garnier z Langres, Allegoriae in universam sacram scripturam. Ventus (PL 112,1074A. Tekst poprawiony na podstawie Ms. 539 z Clairvaux, 108v). 


\section{Duch Święty jako woda}

Kolejnym symbolem o silnej wymowie macierzyńskiej i ponerologicznej (według klasyfikacji M. Girarda ${ }^{22}$ ) jest woda. Różne jej uwarunkowania fizyczne będą jednak wzbudzać odmienne skojarzenia. Pozytywny sens wody zamkniętej w zbiornikach będzie przeciwstawiany niszczycielskiej mocy wody rwącej i nieokiełznanej. Wody nadziemne, będące we władaniu bóstwa, będą przeciwstawiane wodom naziemnym, a zwłaszcza znajdującym się w głębinach morza, gdzie stanowić będą siedlisko potworów i demonów. Ponadto najważniejsze cechy symbolotwórcze związane z motywem wody dotyczą jej życiodajnej mocy, zdolności do oczyszczania i obmywania, władzy nad ogniem, jak również potencjalności niszczycielskiej.

Zagadnienia związane z biblijną symboliką wody doczekały się licznych opracowań naukowych. K.M. Woschitz opracował ją - od starożytności poprzez świat biblijny, Ojców Kościoła aż po Dantego i Goethego - wobszernej monografii²3; L.P. Jones ${ }^{24}$ skupił się na jej znaczeniu w Ewangelii św. Jana; R.D. Patterson przedstawił symbolikę chmur w Biblii, jak również jej implikacje w starożytności i współcześnie ${ }^{25}$; B. Wodecki ${ }^{26}$ - w artykule poświęconym morzu w Biblii - zwrócił uwagę na religijny wymiar jego symboliki zarówno w Starym, jak i Nowym Testamencie; zaś R. Wróbel ${ }^{27}$ opracował symbolikę morza i łodzi w wypowiedziach Ojców Kościoła.

Skojarzenie Ducha Świętego z wodą opiera się na aluzji do daru „wody żywej”, o którym Jezus mówi podczas rozmowy z Samarytanką przy studni Jakubowej (J 4,10) oraz na tekście J 7,37-39: „Jeśli ktoś jest spragniony, a wierzy we Mnie niech przyjdzie do Mnie i pije! Jak rzekło Pismo: Strumienie wody żywej popłyną z jego wnętrza. A powiedział to o Duchu, którego mieli otrzymać wierzący w Niego"28. Wprawdzie nie znajdujemy w Starym Testamencie literalnego odniesienia do „strumieni wody żywej”, mających popłynąć z wnętrza człowieka wierzącego ${ }^{29}$, niemniej komentarz Ewangelisty sugeruje nawiązanie do daru Ducha Świętego. Idąc

22 Por. Girard, Les symboles dans la Bible; na temat symboliki wody, zob. rozdział 2 (233-297).

23 Por. Woschitz, Fons vitae.

24 Por. Jones, The Symbol of Water.

25 Por. Patterson, „The Imagery of Clouds”, 13-27.

26 Por. Wodecki, „Morze w Piśmie Świętym”, 97-118; na temat aspektu religijnego i symboliki ibidem, 104-118. Motywowi morza w Starym Testamencie poświęciła monografię E. Strömberg Krantz, Des Schiffes Weg mitten im Meer.

27 Por. Wróbel, „Starożytna symbolika morza i łodzi”, 1245-1256.

28 Na postawie tego tekstu najczęściej bywała rozwijana symbolika wody jako Ducha Świętego lub jego darów; zob. Grzegorz Wielki, Moralia, 15,16,20 (CCL 43A,761), 11,10,14 (CCL 43A,593), 19,6,9 (CCL 43A,961); Augustyn, De Trinitate, 15,19,33; Ambroży, De Spiritu sancto, 3,20,154 (PL 16,812B-C); Eucheriusz z Lyonu, Formulae spiritalis intelligentiae [wersja rozszerzona], 4. Aqua (PL 50,747B); Raban Maur, De universo, 11,10 (PL 111,318D); Pseudo-Garnier z Langres, Allegoriae in universam Sacram Scripturam. Aqua (PL 112,860B).

29 Komentarz marginalny z Biblii Edycji Świętego Pawła sugeruje nawiązania do: Wj 17,1n; Iz 43,20; 44,3; 58,11; Ez 47,1;Za 14,8. 
tym tropem tradycja chrześcijańska wskazywała szereg miejsc w Starym Testamencie, w których symbol wody mógłby odnosić się do Ducha Świętego.

W dziele encyklopedycznym Distinctiones dictionum theologicalium Alan z Lille wyjaśnia Ps 1,3 („I będzie jak drzewo zasadzone nad nurtami wód”) jako alegorię człowieka świętego, który czerpie życiodajną siłę od Ducha Świętego. Wskazuje przy tym na trzy charakterystyki wody, które czynią z niej symbol Ducha Świętego. Po pierwsze, woda orzeźwia człowieka, w nawiązaniu zaś do sceny Zwiastowania Najświętszej Maryi Pannie (Łk 1,35), Duch jest tym, który orzeźwia (refrigerat). Po drugie, woda zaspokaja pragnienie, Duch zaś - zgodnie z Syr 15,3 („Nakarmi go chlebem rozumu i napoi go wodą mądrości”) - poi mądrością oraz - na podstawie J 7,37 („Jeśli ktoś jest spragniony, a wierzy we Mnie - niech przyjdzie do Mnie i pije”) stanowi doskonały napój gaszący wszelkie łaknienie. Po trzecie, woda płynie swoim własnym nurtem, podobnie jak Duch, który według J 3,8 „wieje tam, gdzie chce”30.

\section{a. Źródło ogrodów, studnia wód żywych (Pnp 4,15)}

Częstym obrazem biblijnym generującym skojarzenie z Duchem Świętym jest metafora źródła lub studni (Pnp 4,15: Fons hortorum, puteus aquarum viventium) znajdującej się pośrodku ogrodu symbolizującego Oblubienicę z Pieśni nad Pieśniami. W interpretacji chrześcijańskiej staje się ona alegorią Kościoła. Poetycko rozwija tę metaforę Gilbert Foliot (+1187), ukazując Ducha Świętego jako boską siłę sprawczą, dzięki której powstają nasiona, kwiaty i owoce ubogacające swoją różnorodnością rozmaite wspólnoty eklezjalne ${ }^{31}$. Z nieco innej perspektywy misterium pojednanej różnorodności Ducha ujmuje Paschazjusz Radbertus (+860), który w poszczególnych motywach literackich opisu ogrodu widzi rozmaite sposoby postrzegania działającej w Kościele łaski Ducha Świętego: dla jednych tą łaską jest tryskająca krynica, dla innych studnia, ogród zamknięty i źródło zapieczętowane, dla jeszcze innych rzeka przepływająca przez ogród ${ }^{32}$.

Oba powyższe ujęcia znajdują połączenie w interpretacji Filipa z Harveng (+1183). Samo źródło znajdujące się w ogrodzie Kościoła obrazuje Ducha Świętego, natomiast życiodajne wody, które z niego wypływają, są darami świętości, orzeźwienia, oczyszczenia lub radości, jakimi Duch obdarza tych wiernych, którzy pragną zjednoczenia z Chrystusem ${ }^{33}$. Niewykluczone, że inspiracją dla takiego odczytania alegorycznego był komentarz do Pieśni nad Pieśniami Angelomusa z Luxeuil (+895), dla którego studnią jest Duch Święty, zaś wypływającą wodą - różne dary, które podtrzymują życie duchowe ${ }^{34}$.

\footnotetext{
30 Por. Alan z Lille, Distinctiones dictionum theologicalium. Aqua (PL 210,705B).

31 Por. Gilbert Foliot, Expositio in Cantica canticorum, ad loc. (PL 202,1266B).

32 Por. Paschaziusz Radbertus, Expositio in Lamentationes Hieremiae. Phe, 3,48 (CCCM 85,215).

33 Por. Filip z Harveng, Moralitates in Cantica canticorum, ad loc. (PL 203,503A).

34 Por. Angelomus z Luxeuil, Enarrationes in Cantica canticorum (PL 115,611C).
} 
Podobnie jak wcześniejsi autorzy, również Ryszard ze św. Wiktora (+1173) utożsamia wody żywe z darami łaski Ducha Świętego, natomiast w studni miłosnego poematu widzi alegorię Kościoła, który został napełniony łaską i mądrością Ducha Świętego i obdarza nią innych ${ }^{35}$.

\section{b. Strumień rozkoszy Bożej (Ps 35,9)}

Sformułowanie Torrens voluptatis tuae (strumień twojej rozkoszy) pojawia się w Ps 35,9 w kontekście obietnicy danej tym, którzy pokładają ufność w Bogu. Wersja Wulgaty różni się względem tekstu hebrajskiego użyciem liczby pojedynczej: w miejsce voluptas tua („twoja rozkosz”) czytamy ădānejkā („twoje rozkosze”): „Sycą się tłuszczem Twojego domu, poisz ich strumieniem Twoich rozkoszy”.

Już Augustyn ${ }^{36}$ przywołuje ten werset jako profetyczny obraz obfitości zatopienia (inundatio) w Duchu Świętym i tę właśnie symbolikę znajdziemy w glosariuszu Eucheriusza z Lyonu ${ }^{37}$. Późniejsi komentatorzy doprecyzują, iż strumień boskich rozkoszy, jako doskonały napój duchowy, oznaczać będzie dary Ducha Świętego ${ }^{38}$, a dusza nawodniona tym potokiem rodzić będzie owoce świętości ${ }^{39}$. Wspaniale w formie modlitwy wyrazi tę myśl Anzelm z Canterbury (+1109): „O krynico życia, napełnij myśl moją strumieniem Twojej rozkoszy i pokrzep me serce orzeźwiającym upojeniem Twej miłości, abym poniechał tego, co próżne i przyziemne a Ciebie tylko trwale miał w swej pamięci, jak jest napisane: Pamiętałem o Bogu i rozradowałem się” (Ps 76,4). „Obdaruj mnie Duchem Świętym, którego oznaczają owe wody, które dać obiecałeś spragnionym" 40 .

\section{c. Bystrość rzeki dająca radość miastu Bożemu (Ps 45,5)}

W kontekście opiekuńczej troski Boga o święte miasto Jeruzalem, w którym wznosi się Jego przybytek, znajdujemy obraz płynącej rzeki, która daje radość (Fluminis impetus laetificant civitatem Dei; Ps 45,5). Wprawdzie w Wulgacie znajdujemy słowo impetus (impet, przypływ, gwałtowność, bystrość) w liczbie mnogiej, o czym świadczy towarzysząca mu forma czasownikowa, tym niemniej w tekście hebrajskim mowa jest o odnogach lub kanałach irygacyjnych (pelāgājw). Ogólna wymowa w obu przypadkach jest podobna, aczkolwiek o ile symbolika rzeki sugerowałaby odniesie-

\footnotetext{
35 Por. Ryszard ze św. Wiktora, Explicatio in Cantica canticorum (PL 196,491C).

36 Por. Augustyn, Sermones de Scripturis, 32,6 (PL 38,198).

37 Por. Eucheriusz z Lyonu, Formulae spiritalis intelligentiae. Torrens (CSEL 31,22).

38 Por. Raban Maur, De universo (PL 111,595A).

39 Por. Gerhohus z Reichesberg, Commentarius aureus in Psalmos et cantica ferialia, ad Ps 35 (PL 193,1353A).

40 Fons vitae, reple mentem meam torrente voluptatis tuae, et inebria cor meum sobria ebrietate amoris tui; ut obliviscar quae vana sunt et terrena, et te solum iugiter habeam in memoria mea, sicut scriptum est: Memor fui Dei, et delectatus sum (Ps 76, 4). Da mihi Spiritum sanctum tuum, quem significabant illae aquae, quas sitientibus daturum te promiseras (Anzelm z Canterbury, Orationes, 18 [PL 158,898B]; tekst polski $\mathrm{w}$ tłumaczeniu własnym).
} 
nie do Ducha Świętego, o tyle mnogość łacińskich impetus lub hebrajskich pelāgîm mogłaby raczej przywodzić na myśl różnorodność Jego darów.

Werset 5 przywołany został w odniesieniu do Ducha Świętego dwukrotnie przez Augustyna. Raz w ramach wyjaśnień zawartych w komentarzu do Psalmów $w^{41}$, drugi zaś - w kontekście homiletycznym, w towarzystwie wersetu omawianego w poprzednim paragrafie ${ }^{42}$. W obu przypadkach kontekst sugeruje eklezjalne odniesienie określenia Civitas Dei.

Zapewne odwołując się do Augustyna, Ps-Garnier z Langres ${ }^{43}$ zamieścił interpre- $^{-}$ tację pneumatologiczną jako pierwszą pośród wyjaśnień hasła flumen. Warto jednak zauważyć, że o ile w oryginalnej wersji ${ }^{44}$ dzieła strumień symbolizuje Ducha Świętego (Spiritus Sanctus), o tyle wydanie Patrologia Latina Jacquesa Paula Migne’a - łaskę Ducha Świętego (Spiritus Sancti gratia).

\section{d. Uderzył w skałę i popłynęły wody (Ps 77,20)}

Psalm 77 (w numeracji Wulgaty) stanowi swoistą relekturę wydarzenia paradygmatycznego w dziejach Izraela, jakim jest wyjście z Egiptu. Pośród znaków Bożej Opatrzności, na jakie powołuje się autor, został wymieniony epizod wyprowadzenia wody ze skały, w którą Mojżesz uderzył swoją laską: percussit petram et fluxerunt aquae („,uderzył w skałę i popłynęły wody”; Ps 77,20).

Już w Nowym Testamencie znajdujemy typologiczną interpretację tego wydarzenia, gdy św. Paweł pisze do Koryntian, nawiązując do Izraelitów wędrujących przez pustynię: „Pili ten sam duchowy napój. Pili zaś z towarzyszącej im duchowej skały, a ta skała - to był Chrystus" (1Kor 10,4). Na kanwie tego fragmentu Rupert z Deutz ${ }^{45}$ (+1129), tworząc swoją typologiczną syntezę dziejów zbawienia, rozwija interesującą alegorię. Skałą, podobnie jak u św. Pawła, jest Jezus Chrystus, natomiast uderzenie w nią - o czym Paweł nie wspomina - symbolizuje uderzenie w Chrystusa, a więc skazanie Go na mękę i śmierć krzyżową. Na tym jednak nie koniec. Konsekwencją misterium paschalnego jest nie tylko nowe życie w Chrystusie, ale i obdarowanie Duchem Świętym, którego Chrsystus posyła w Dniu Pięćdziesiątnicy. Zatem wody, które wypływają ze skały-Chrystusa, to dar Ducha Świętego, w myśl doktryny filioque, obecnej w teologicznej tradycji Kościoła zachodniego, podkreślającej pochodzenie Ducha nie tylko od Ojca, ale i od Syna.

\footnotetext{
41 Por. Augustyn, Enarrationes in Psalmos, in Ps 45,8 (CCL 38,523).

42 Por. Augustyn, Sermones de Scripturis, 32,6 (PL 38,198).

43 Por. Pseudo-Garnier z Langres, Allegoriae in universam Sacram Scripturam. Flumen (PL 112,933C).

44 Wydanie krytyczne oraz polskie tłumaczenie Allegoriae in universam sacram Scripturam Pseudo-Garniera z Langres stanowi przedmiot grantu Narodowego Programu Rozwoju Humanistyki realizowanego przez autora artykułu. 


\section{Duch Święty jako ogień i światło}

Symbolika ognia wpisuje się w podstawową antynomię archetypiczną, jaką jest przeciwstawienie światła i ciemności. Światło jest nośnikiem wszystkiego, co dobre. Od najdawniejszych czasów światło kojarzyło się z możliwością percepcji wizualnej, co w konsekwencji prowadziło do poczucia bezpieczeństwa, możliwości panowania nad otoczeniem oraz jego poznawania. Ciemność - przeciwnie - ograniczała percepcję, uniemożliwiała przewidzenie zagrożenia, ograniczała poznanie otoczenia i utrudniała panowanie nad nim, wzbudzając poczucie bezsilności oraz lęku. Jednak - jak zaznacza Girard ${ }^{46}$ - poza pozytywnymi cechami symbolotwórczymi, do których należą emisja ciepła i światła oraz zdolność do oczyszczania i regeneracji, ogień jest również potężną siłę generującą zniszczenie.

Spośród licznych opracowań naukowych, dotyczących problematyki ognia i światła, warto wymienić ważniejsze przykłady. Symbolikę ognia w tekstach biblijnych opracował I.M. Sans ${ }^{47}$. Artykuł na temat światła jako symbolu religijnego napisał J. Macquarrie ${ }^{48}$, a światła w Ewangelii św. Jana - J. Klinkowski ${ }^{49}$. Związaną z ogniem symbolikę tygla jako metafory śmierci i odrodzenia omówiła P.M. McNutt ${ }^{50}$.

Anonimowy autor, który poszerzył spuściznę homiletyczną Bedy Czcigodnego (+735), przypisując mu autorstwo licznych dodatkowych kazań, odnosi do Ducha Świętego dwie podstawowe cechy ognia: rozpala przez miłość oraz oświetla dzięki mądrości ${ }^{51}$. Brunon z Asti $(+1123)$ dodaje jeszcze trzecią właściwość, mianowicie oczyszczenie dzięki spaleniu (consumpsit et purgavit): dar Ducha Świętego sprawił, że stary grzech został wypalony w sercach apostołów. Ponadto zwraca on uwagę, że wraz z rozpaleniem miłości, ogień Ducha ogrzewa (calefacit) ${ }^{52}$. Hildegarda z Bingen (+1179) nazywa Ducha Świętego płomieniem, który rozpala w duszy zamiar czynienia dobra ${ }^{53}$.

Co się tyczy nowotestamentowych skojarzeń Ducha Świętego z ogniem, to na pierwszy plan wysuwają się dwa teksty. Najważniejszym jest oczywiście zamieszczony w Dziejach Apostolskich opis Zesłania Ducha w dniu Pięćdziesiątnicy, w szczególności obraz języków ognia, które spoczęły na apostołach zgromadzonych w wieczerniku (Dz 2,3). Konsekwencje tego wydarzenia zwięźle przedstawia Ambroży

\footnotetext{
46 Por. Girard, Les symboles dans la Bible; na temat symboliki ognia zob. rozdział 1 (111-231).

47 Por. Sans, „Dios Fuego”, 73-97.

48 Por. Macquarrie, „Symbolism Case Study”, 396-409.

49 Por. Klinkowski, „Symbolika światłości”, 57-71. Bez odniesień do tradycji interpretacyjnej w starożytności chrześcijańskiej.

50 Por. McNutt, „Egypt as an «Iron Furnace»”, 293-301.

51 Por. Pseudo-Beda, Homiliae. Homilia 30 in dominica quarta Adventus (PL 94,332D).

52 Por. Brunon z Asti, Sententiae, 4. Sermo 1 de adventu Spiritus Sancti (PL 165,1017B).

53 Por. Hildegarda $\mathrm{z}$ Bingen, Liber divinorum operum simplicis hominis, visio 4,49 (PL 197,841C).
} 
z Mediolanu: Duch posłany po wniebowstąpieniu Jezusa oczyścił ze wszystkich grzechów oraz rozpalił ducha i umysł wiernych ${ }^{54}$.

Drugi tekst nowotestamentowy to Łk 12,49: „Przyszedłem ogień rzucić na ziemię i jakże bardzo pragnę, aby już zapłonął”. Wprawdzie kontekst wypowiedzi wskazuje na eschatologiczny wymiar Jezusowego logionu, w którym ogień ma symbolizować zbliżający się sąd i motywować do zdecydowanego wejścia na drogę prowadzącą do królestwa Bożego ${ }^{55}$, niemniej jednak tradycja dostrzega tu aluzję do obietnicy posłania Ducha Świętego, ukrytego w symbolice ognia. Według Grzegorza Wielkie$\mathrm{go}^{56}$ pragnienie Jezusa spełniło się w dniu Pięćdziesiątnicy, zaś Aelred z Rievaulx ${ }^{57}$ $(+1167)$ rozciąga jego zasięg - w kontekście kaznodziejskim - na serca wiernych słuchających słowa Bożego. W wyniku kwerendy starotestamentalnych tekstów odwołujących się symbolicznie do Ducha Świętego jako ognia i światła, chcielibyśmy zwrócić uwagę na cztery szczególnie istotne.

\section{a. Duch Święty jako płomień Bożej chwały (Ez 1,27)}

Wizja chwały Bożej z Ez 1 zawiera opis lśniącego blaskiem stopu złota ze srebrem, który niczym ogień otaczał postać siedzącą na tronie. Hieronim - w przekładzie Wulgaty - wyraził to słowami: „Jakby wygląd ognia wewnątrz niego dookoła, od jego bioder wzwyż, a od jego bioder w dół widziałem jakby blask ognia jaśniejącego wokoło" (velut aspectum ignis intrinsecus eius per circuitum a lumbis eius et desuper et a lumbis eius usque deorsum vidi quasi speciem ignis splendentis in circuitu; Ez 1,27).

$\mathrm{Na}$ podstawie ponaddosłownej interpretacji tego fragmentu wodniesieniu do Ducha Świętego ${ }^{58}$, Grzegorz Wielki przedstawia w skrócie dzieje zbawienia: najpierw („od bioder wzwyż”) Duch Święty obecny był jedynie w ludzie Pierwszego przymierza, Izraelu, natomiast po Wcieleniu Jezusa Chrystusa („od bioder w dół”) blask Ducha zaczął jaśnieć po całym świecie, „ponieważ miłość Wszechmogącego Boga zaczęła rozwijać się we wszystkich narodach aż po krańce świata" ${ }^{9}$.

\section{b. Duch Święty jako ogień oczyszczający (Iz 10,17)}

Drugi tekst, na który chcielibyśmy zwrócić uwagę, pochodzi z Księgi Izajasza. W pełnej grozy wyroczni skierowanej przeciwko Asyrii, prorok w następujący sposób przedstawia Boga: „I będzie światłość Izraela ogniem, a Święty jego płomieniem, i będą spalone i pożarte ciernie jego i głogi dnia jednego" (Et erit lumen Israhel in

\footnotetext{
54 Por. Ambroży, De officiis ministrorum, 3,18,102 (PL 16,174C).

55 Por. Mickiewicz, Ewangelia według świętego Łukasza, 73.

56 Por. Grzegorz Wielki, Concordia quorumdam testimoniorum S. Scripturae, 12 (PL79,666B).

57 Por. Aelred z Rievaulx, Sermones de tempore. Sermo 23. De omnibus sanctis (PL195,347B).

58 Por. Grzegorz Wielki, Homiliae in Ezechielem, Hom. 8,26 (SCh 327,314).

59 Quae ardoris flamma visa est postmodum in circuitu splendere, quia per mundi cardines in universis gentibus omnipotentis Dei coepit amor excrescere (Grzegorz Wielki, Homiliae in Ezechielem, 314 [ŹM 81, 269]).
} 
igne et Sanctus eius in flamma et succendetur et devorabitur spina eius et vepres in die una; Iz 10,17).

Tę szczególną moc oczyszczającą Augustyn przypisuje Duchowi Świętemu. To On poprzez działanie sakramentalne objawia majestat Boga, mającego moc uświęcenia przez ogień ${ }^{60}$. Powołując się na słowa biskupa Hippony, Herveus z Déols $(+1149)$ doprecyzuje, że tym, co zostaje unicestwione ogniem Ducha Świętego w sakramencie chrztu, jest grzech pierworodny, który symbolizują ciernie oraz „szorstkość grzesznych nałogów" (vitiorum asperitates) wyrażoną w sposób ponaddosłowny przy pomocy obrazu głogów ${ }^{61}$.

\section{c. Duch Święty jako światło Bożego Oblicza (Ps 4,7)}

W ikonosferze biblijnych symboli ma swoje miejsce również interpretacja Trójcy świętej jako organicznej jedności ciała. Chrystus przedstawiany bywał jako ramię, prawica lub usta Boga, natomiast Duch Święty jako Jego język lub palec ${ }^{62}$. W tym kluczu starożytna tradycja interpretowała również Ps 4,7, który w przekładzie Wulgaty brzmi: „Znakiem jest nad nami światłość oblicza twego, Panie, dałeś wesele w serce moje" (signatum est super nos lumen vultus tui, Domine, dedisti laetitiam in corde meo).

Tą światłością oblicza Bożego jest Duch Święty. Ambroży z Mediolanu sytuuje tę interpretację w liturgicznym kontekście chrzcielnym, gdzie termin signatum skojarzony został z opieczętowaniem (signaculum) Duchem Świętym, jak określano sakrament chrztu ${ }^{63}$. Również w odniesieniu do chrztu, a w szczególności namaszczenia Duchem, odczytuje te słowa Beda Czcigodny ${ }^{64}$, podczas gdy Raban Maur (+856) odnosi sens wersetu do światła wiary lub daru Ducha Świętego w szerszym znaczeniu niż tylko sakramentalne $e^{65}$.

\section{d. Duch Święty jako źródło żaru miłości (Pnp 8,6)}

W ostatnim rozdziale Pieśni nad Pieśniami Oblubienica kieruje do swego Umiłowanego słowa: „Bo mocna jest jak śmierć miłość, twarda jak otchłań jest zazdrość; pochodnie jej pochodnie ognia i płomieni" (Quia fortis est ut mors dilectio dura sicut inferus aemulatio, lampades eius lampades ignis atque flammarum; Pnp 8,6). Jest to fragment wspaniałego hymnu o miłości, który doczekał się licznych interpretacji w starożytności i średniowieczu.

\footnotetext{
60 Por. Ambroży, De Spiritu Sancto, 1,14,144 (PL 16,737D).

61 Por. Herveus z Déols, Commentaria in Isaiam, 2,10,17 (PL 181,133D).

62 Zob. Bardski, Lektyka Salomona, 371.

63 Por. Ambroży, De Spiritu Sancto, 1,14,149 (PL 16,738C).

64 Por. Beda, In Lucae Evangelium expositio, ad 22,39 (CCL 120,385).

65 Por. Raban Maur, De universo, 9,7 (PL 111,266D).
} 
Większość komentatorów symbolikę pochodni odnosi do dusz świętych i wiernych chrześcijan, jednak jedynie u Pseudo-Anzelma z Laon ${ }^{66}$ znajdujemy interpretację pneumatologiczną, która rozwija sens Pnp 8,6: to Duch Święty obdarza wiernych ciepłem i światłem miłości i uzdalnia ich do tego, aby innych oświecali słowem i przykładem ${ }^{67}$.

\section{Konkluzja}

Badając symboliczną ikonosferę starożytnej i średniowiecznej tradycji chrześcijańskiej, możemy stwierdzić, że odwołanie się do podstawowych żywiołów przyrody stanowiło jeden z ważniejszych sposobów unaoczniania niewidzialnej rzeczywistości, jaką jest Duch Święty. Wydobywanie specyficznych motywów literackich zawartych w Biblii, podatnych na ponaddosłowną twórczość interpretacyjną, pozwala nam uchwycić ważne skojarzenia, obecne w tradycji Kościoła.

Symbol wiatru, który w starożytnej i średniowiecznej tradycji Kościoła przywoływał ciepło pochodzące od prawdziwego źródła, jakim jest Jezus Chrystus, może w wyobraźni współczesnych chrześcijan kojarzyć się również ze swoistą zmiennością i nowością. Wiatr zawsze przynosi zmianę pogody, często nieoczekiwaną. Może też wyrażać dynamizm zmieniającej się rzeczywistości - tak podkreślaną obecnie płynność czasów ponowoczesnych, kiedy w niespotykanym dotychczas tempie zmieniają się paradygmaty, modele i wzorce opisujące rzeczywistość w nas i wokół nas.

Również symbol wody, który w tradycji przywoływał źródło ogrodu-Kościoła z Pieśni nad Pieśniami oraz strumień rzeki dającej życie wspólnocie wierzących, wspaniale wpisuje się we współczesne zaangażowanie ekologiczne. Woda, jako źródło życia na naszej planecie, stanowi przedmiot wspólnej troski oraz budzi skojarzenia związane z jej rolą.

Ogień, jako symbol Ducha Świętego, zapraszał w dziejach Kościoła do tworzenia skojarzeń z płomieniem dającym światło oraz z żarem Bożej miłości. Również dzisiaj, w dobie szczególnego zwrócenia uwagi na tajemnicę Bożego miłosierdzia, symbolizowaną chociażby promieniami światła z Serca Jezusowego, symbol ognia jako Ducha Świętego może szczególnie przemawiać do wyobraźni współczesnego człowieka.

Ponadto zauważmy, że wszystkie powyższe żywioły natury posiadają przynajmniej trzy cechy wspólne. Są to: potęga działania, przekraczanie wszelkich ograniczeń oraz swoista ambiwalencja.

66 Na temat atrybucji dzieła zob. Bardski, Słowo oczyma Gołębicy, 265.

67 Por. Pseudo-Anzelm z Laon, Enarrationes in Cantica canticorum, ad 8,6 (PL 162,1225C). 
Pierwszą z nich wydaje się fakt, iż potężne moce natury, jako stworzone przez Boga, uwidaczniają Jego moc i potęgę, a tym samym, na płaszczyźnie wyobraźni, mogą przywoływać na myśl Jego samego. Oczywiście nie chodzi o oddawanie czci siłom przyrody, ale postrzeganie - poprzez ich skuteczność - działania Ducha Bożego w świecie i Kościele.

Po drugie, należy też zwrócić uwagę na uniwersalny wymiar sił natury. Nie respektują one granic i obostrzeń ustanowionych przez ludzi i oddziaływają na każdego bez żadnej różnicy. Wskazuje to na powszechność i wolność działania Ducha Świętego oraz Jego moc przekraczania ograniczeń.

Po trzecie, nie można zapomnieć o ambiwalencji symboliki żywiołów. W zależności od kontekstu stanowią one życiodajną lub niszczycielską siłę. W przypadku odniesienia symboliki do Ducha świętego, ów destrukcyjny charakter dotyczy oczywiście możliwości pokonania zła i grzechu, niepokoju, zniechęcenia i smutku.

\section{Bibliografia}

\section{Magisterium Kościoła}

Benedykt XVI, Verbum Domini (2010).

Sobór Watykański II, Dei verbum (1965).

\section{Dzieła Ojców Kościoła i pisarzy średniowiecznych}

Aelred z Rievaulx, In adventu Domini (PL 184,817-828).

Aelred z Rievaulx, Sermones de tempore (PL 195,209-360).

Alan z Lille, Distinctiones dictionum theologicalium (PL 210,687-1012).

Alkuin (Pseudo-Beda), De divinis officiis (PL 101,1173-1286).

Ambroży, De officiis ministrorum (PL 16,25-194).

Ambroży, De Spiritu sancto (red. O. Faller) (CSEL 79; Wien: Hoelder - Pichler - Tempsky 1964); PL 16,703-742; tłum. A. Strzelecka: Ambroży, O Duchu Świętym (POK 31; Poznań: WT UAM 2015).

Angelomus z Luxeuil, Enarrationes in Cantica canticorum (PL 115,551-628).

Anzelm z Canterbury, Orationes (PL 158,855-1016).

Anzelm z Laon (Pseudo), Enarrationes in Cantica canticorum (PL 162,1187-1227).

Augustyn, De Trinitate (red. W.J. Mountain - F. Gloire) (CCL 50-50A; Turnholti: Brepols 1968). Augustyn, Enarrationes in Psalmos (red. E. Dekkers - J. Fraipont) (CCL 38-40; Turnholti: Brepols 1956); tłum. J. Sulowski: Augustyn, Objaśnienia Psalmów (PSP 37-42; Warszawa: Akademia Teologii Katolickiej 1986).

Augustyn, Quaestiones in Heptateuchum (red. J. Fraipont) (CCL 33, Turnholti: Brepols 1958); tłum. J. Sulowski: Augustyn, Problemy Heptateuchu,, PSP 46-47; Warszawa: Akademia Teologii Katolickiej 1990).

Augustyn, Sermones de Scripturis (PL 38, 23-994).

Beda, In Lucae Evangelium expositio (red. D. Hurst) (CCL 120; Turnholti: Brepols 1960). 


\section{KRZYSZTOF BARDSKI}

Beda (Pseudo), Commentarii in Pentateuchum. Exodus (PL 91,285-332).

Beda (Pseudo), Homiliae (PL 94,267-516).

Brunon z Asti, Sententiae (PL 165,875-1078).

Brunon z Würzburga, Expositio Psalmorum (PL 142,39-530).

Eucheriusz z Lyonu, Formulae spiritalis intelligentiae (PL 50,727-772 [wersja dłuższa z interpolacjami z Bedy]); (red. C. Wotke) (CSEL 31; Vindobonae: Tempsky - Lipsiae: Freytag 1894) 3-62 [wersja krótsza].

Filip z Harveng, Moralitates in Cantica canticorum (PL 203,181-490).

Garnier z Langres (Pseudo), Allegoriae in universam sacram scripturam (PL 112,849-1088).

Gerhohus z Reichesberg, Expositio in canticum Habacuc (PL 194,1027-1046).

Gilbert Foliot, Expositio in Cantica canticorum (PL 202,1147-1304).

Gerhohus z Reichesberg, Commentarius aureus in Psalmos et cantica ferialia (PL 193,619-1814)

Grzegorz Wielki, Concordia quorumdam testimoniorum S. Scripturae (PL 79,659-678).

Grzegorz Wielki, Homiliae in Ezechielem, lib. 1-2; Homélies sur Ézéchiel (red. Ch. Morel) (SCh 327-360;, Paris: Cerf 1986-1990) I-II; tłum. A. Wilczyński: Grzegorz Wielki, Homilie na Księgę Ezechiela (Źródła Monastyczne 81; Kraków: Tyniec 2019) I.

Grzegorz Wielki, Moralia in Job [lib. 23-35] (red. M. Adriaen) (CCL 143B; Turnholti: Brepols 1985); tłum. A. Wilczyński: Grzegorz Wielki, Moralia. Komentarz do Księgi Hioba. V. Księgi XXIII-XXVII (Źródła Monastyczne 75; Kraków: Tyniec 2015).

Herveus z Déols, Commentaria in Isaiam (PL 181,17-592).

Hildegarda z Bingen, Liber divinorum operum simplicis hominis (PL 197,741-1038).

Jan z Rouen, De officiis ecclesiasticis. Ad Maurilium (PL 147,27-62).

Paschaziusz Radbertus, Expositio in Lamentationes Hieremiae libri quinque (red. B. Paulus) (CCCM 85; Turnhout: Brepols 1988).

Piotr Lombard, Commentaria in Psalmos (PL 191,55-1296).

Raban Maur, De universo (PL 111,9-614).

Rupert z Deutz, Commentariorum in duodecim prophetas minores (PL 168,9-836).

Rupert z Deutz, De Sancta Trinitate et operibus eius (red. H. Haacke) (CCCM 21-24; Turnholti: Brepols 1971-1972).

Ryszard ze św. Wiktora, Explicatio in Cantica canticorum (PL 196,405-524).

\section{Opracowania współczesne}

Bardski, K., Lektyka Salomona. Biblia - symbol - interpretacja (Rozprawy Naukowe 6; Warszawa: WAW 2011).

Bardski, K., Słowo oczyma Gołębicy. Metodologia symboliczno-alegorycznej interpretacji Biblii oraz jej teologiczne i duszpasterskie zastosowanie (Rozprawy Naukowe 3; Warszawa: WAW 2007).

Cirlot, J.E., Słownik symboli (tł. I. Kania) (Kraków: Znak 2000).

Girard, M., Les symboles dans la Bible. Essai de théologie biblique enracinée dans l'expérience humaine universelle (Montréal: Bellarmin - Paris: Cerf 1991).

Jones, L.P., The Symbol of Water in the Gospel of John (JSNTSup 145; Sheffield: Sheffield Academic Press 1997).

Klinkowski, J., „Symbolika światłości według św. Jana na tle starożytnej kultury”, Wrocławski Przegląd Teologiczny 18/1 (2010) 57-72. 


\section{DUCH ŚWIĘTY JAKO ŻYWIOŁY NATURY W SYMBOLICZNYCH INTERPRETACJACH}

Macquarrie, J., „Symbolism Case Study: Light as a Religious Symbol”, The Bible in its Literary Milieu. Contemporary Essays (red. V.L. Tollers - J.R. Maier) (Grand Rapids, MI: Eerdmans 1979) 396-410.

McNutt, P.M., „Egypt as an «Iron Furnace»: A Metaphor of Transformation - A Writer's Perspective", Society of Biblical Literature. Seminar Papers Series 27 (1988) 293-301.

Mickiewicz, F., Ewangelia według świętego Łukasza (Częstochowa: Święty Paweł 2012) II

Patterson, R.D., „The Imagery of Clouds in the Scriptures”, Bibliotheca Sacra 165/1 (2008) 13-27.

Sans, I.M., „Dios Fuego”, Estudios Eclesiásticos 77/1 (2002) 73-97.

Strömberg Krantz, E., Des Schiffes Weg mitten im Meer. Beiträge zur Erforschung der nautischen Terminologie des Alten Testaments (Coniectanea Biblica. Old Testament Series 19; Lund: Gleerup 1982).

Wiggins, S.A., „Tempestuous Wind Doing Yhwh's Will: Perceptions of Wind in the Psalms”, Scandinavian Journal of the Old Testament 13/1 (1999) 3-23.

Wodecki, B., „Morze w Piśmie Świętym”, Ruch Biblijny i Liturgiczny 58/2 (2005) 97-118.

Woschitz, K.M., Fons vitae - Lebensquell. Sinn- und Symbolgeschichte des Wassers (Forschungen zur europäischen Geistesgeschichte 3, Freiburg: Herder 2003).

Wróbel, R., „Starożytna symbolika morza i łodzi w wypowiedziach Ojców Kościoła”, Vox Patrum 52 (2008) 1245-1256. 
